\title{
Investigating a neglected part of Schumpeter's creative army: what drives new-to-the-market innovation in micro-enterprises?
}

\author{
Stephen Roper (iD • Nola Hewitt-Dundas
}

Accepted: 13 February 2017 / Published online: 18 March 2017

(C) The Author(s) 2017. This article is published with open access at Springerlink.com

\begin{abstract}
Schumpeterian arguments related to creative destruction place small, entrepreneurial firms at the centre of the innovation process. The exclusion of microenterprises (with less than 10 employees) from most innovation surveys means, however, that we know relatively little about innovation among this group of firms. Here, using new survey data on a thousand micro-enterprises, we explore the determinants of new-to-the-market innovation, the basis for the Schumpeterian creative destruction (CD) process. Our results provide strong support for the interactive nature of micro-enterprise innovation and suggest the potential value of a model of interactive creative destruction (ICD). Contrary to some other recent evidence, market-based and supplier-based collaboration both prove important for new-to-the-market innovation. Our results suggest the importance of micro-enterprises as sources of new-to-the-market innovation and the potential value of including such firms in future innovation studies.
\end{abstract}

Keywords Innovation $\cdot$ Micro-enterprise $\cdot$ Creative destruction

JEL Classification $\mathrm{O} 32 \cdot \mathrm{L} 1 \cdot \mathrm{O} 38 \cdot \mathrm{Q} 34 \cdot \mathrm{L} 26$

\section{S. Roper $(\bowtie)$}

Enterprise Research Centre and Warwick Business School, University of Warwick, Coventry CV4 7AL, UK

e-mail: Stephen.roper@wbs.ac.uk

N. Hewitt-Dundas

Enterprise Research Centre and Queen's Management School, Queen's University Belfast, Belfast BT9 5EE, UK

e-mail: Nm.hewitt@qub.ac.uk

\section{Introduction}

Schumpeterian arguments related to creative destruction (CD) place small, entrepreneurial firms at the centre of the innovation process. Here, opportunistic entrepreneurs invest in new technology and commercialisation and, for a limited time, through innovation, achieve a position of market leadership. In reality, such processes are hard to observe systematically, both due to the dynamic nature and potential rapidity of the process of creative destruction itself but also due to practical difficulties associated with identifying the firms involved. Studies of emergent clusters or industries (Diaz Perez et al. 2011; Diaz Perez et al. 2011) and those focussed on start-ups probably come closest (Ganotakis and Love 2011) although, even here, the creative destruction process tends to be observed as historical rather than current phenomena. More generally, innovation studies, many of which are based on datasets such as the EU Community Innovation Survey, exclude micro-enterprises with less than $10 \mathrm{em}$ ployees as these are excluded from EU surveys.

While a focus on larger firms in innovation surveys may be regarded as a pragmatic decision, it means we have very little robust evidence on the drivers of innovation in micro-firms (Tu et al. 2014). A priori, however, we might anticipate that micro-businesses operate very differently to larger firms in terms of their innovation process (Cohen and Klepper 1996), investment in R\&D (Baumann and Kritikos 2016), and particularly in relation to partnering (Kim and Vonortas 2014). Microbusiness owners may, for example, over-estimate the risks associated with pursuing growth and innovation 
(Allinson et al. 2006). Innovation partnerships with other organisations may help micro-firms share these risks, overcome any innate conservatism and make positive strategic decisions. Internal resource constraints, reflected in arguments about the liability of smallness (Carroll 1983), may also shape how micro-firms innovate, forcing firms with an ambition to innovate to access external resources for innovation through collaboration. Lack of scale may also make appropriating the benefits of innovation more difficult for micro-businesses, and here too, partnering with larger organisations may yield significant benefits.

The potential importance of partnering for microbusiness innovation suggests the value of augmenting the traditional CD model in which firms introducing new-to-the-market innovations gain a position of market leadership. In the original CD model, the process of technological change and innovation is seen as atomistic, undertaken by individual firms, where innovation is based primarily on the firms' internal capabilities. This 'closed', and essentially linear, view of innovation today seems rather naïve. Instead, we increasingly understand innovation as an interactive or social process, shaped strongly by firms' external relationships (Metcalfe 1997), something which may be particularly important for innovating micro-businesses. These relationships may be interactive - partnerships or formal R\&D collaborations - or non-interactive - involving copying, reverse engineering or imitation (Glückler 2013). Either way, the evidence from studies of innovation in small and medium enterprises (SMEs) emphasises the importance of external knowledge in contributing to firms' innovation success (Vahter et al. 2014). ${ }^{1}$ This emphasises the role of absorptive capacity and firms' capabilities in integrating external and internal knowledge in what we refer to as interactive CD or ICD.

Empirically, we have little evidence on the nature of micro-business innovation. Two recent studies, both based on bespoke surveys and relatively small samples (c. 150 firms), provide some insights, examining the impact of internal factors on innovation in Spanish micro-enterprises (Benito-Hernandez et al. 2012), and of supply chain co-operation in Chinese night markets (Tu et al. 2014). Here, we add to this very limited evidence base using data from a large-scale survey of 1000 micro-businesses in Northern Ireland (Department

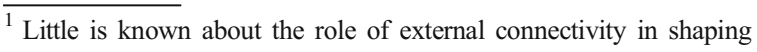
innovation in micro-enterprises, although see Tu et al. (2014).
}

of Enterprise 2014). We make three main empirical contributions. First, our data is unusual in providing detailed information on the innovative activities of a large group of micro-firms, and this provides new insights into the creative destruction process for this under-studied group of firms. What proportion of micro-enterprises, for example, are introducing new-tothe-market innovations of the type envisaged in the creative destruction model? Second, as our data includes a range of innovation metrics in common with the EU Community Innovation Surveys, we are able to make comparisons with larger firms. This enables us to examine whether new-to-the-market innovation is more common among micro-enterprises than larger firms as the CD model might suggest. Finally, reflecting the entrepreneurial nature of micro-firms, we are able to examine how the leadership and ownership characteristics of micro-businesses influence which micro-enterprises take the lead in the creative destruction process (Kellermanns et al. 2012; Kotlar et al. 2014; Kraus et al. 2012).

The remainder of our paper is organised as follows. Section 2 outlines our conceptual perspective focussing on interaction and its role in stimulating new-to-themarket innovation. Section 3 specifies our hypotheses drawing on what is known about the drivers of small business innovation. Data sources are described in Section 4, which also profiles our estimation approach. Our analysis makes use of a standard innovation production function which relates innovative outputs to knowledge inputs and resources from within the firm alongside the firm's acquisition of external knowledge (Leiponen and Byma 2009; Roper et al. 2008). Section 5 describes our main empirical results.

\section{Conceptual foundations - towards an interactive CD model}

In creative destruction 'the creation is usually accomplished by invaders - new firms or entrants from other industries - while the destruction is suffered by the incumbents'. ${ }^{2}$ Two types of destructive impacts have been identified: competence destroying innovations which undermine or eliminate the value of the assets or technology of incumbents within an existing market

\footnotetext{
$\overline{2}$ Rosenbloom and Christensen (1994, p. 656) as quoted in Bergek et al. (2013).
} 
paradigm and disruptive innovations which change the market paradigm itself (Bergek et al. 2013). Both require innovation which is (at least) new to the market, and both threaten the market position of incumbents which may also be influenced by core-rigidities (Leonard-Barton 1992) and inertia (Christensen 1997; Lucas and Goh 2009). New entrants may then benefit from 'attackers advantage' and the innovators' potential opportunity to set the ground rules for future competition (Leenders and Voermans 2007; Foster 1986).

Achieving market leading or disruptive innovation, however, requires resources and a willingness to bear risk. The risk associated with any innovation project will depend on both the technological complexity of the project as well as commercial concerns about sales, profitability and potential competition (Keizer and Halman 2007; Roper et al. 2008; Cabrales et al. 2008). Technological risks are associated primarily with the potential failure of development projects to achieve the desired technological or performance outcomes, an inability to develop a solution which is cost-effective to manufacture/deliver (Astebro and Michela 2005) or issues around project development time (Menon et al. 2002; Von Stamm 2003). Each may have implications for innovations' subsequent market success or viability. In terms of development time, for example, it has been suggested that compressed development time may necessitate overly rapid decision making, reducing innovation quality (Zhang et al. 2007) with potentially negative effects on post-innovation returns (Bower and Hout 1988).

The extent to which enterprise size may alter the technological risk of innovation has been the focus of considerable research interest, specifically in relation to R\&D investment. It is accepted that for micro-enterprises, the resources available for investment in R\&D and innovation are more limited than for larger enterprises (Vossen 1998). Baumann and Kritikos (2016) highlight three reasons why this may be the case, relating to threshold levels of R\&D investment (Cohen and Klepper 1996), sunk and fixed costs of conducting formal R\&D (Peters et al. 2013) and information asymmetries (Stiglitz and Weiss 1981) which reduce access to external finance and may be particularly acute for micro-enterprises with limited accumulated profits (Conte and Vivarelli 2014).

Beyond the technological risks, market-related innovation risks have a commercial dimension linked directly to the demand for the innovation but may also involve issues around rivalry or appropriability conditions. Astebro and Michela (2005), for example, emphasise demand instability as one of three main factors linked to reduced innovation survival in their analysis of 37 innovations supported by the Canadian Inventors Assistance Programme. ${ }^{3}$ Market rivalry and competitors' responses may also play a critical role in shaping marketrelated innovation risks. Rivals' new product announcements may reduce returns (Fosfuri and Giarratana 2009), for example, while appropriability conditions may shape firms' ability to benefit from new innovations (Leiponen and Byma 2009). Moreover, as Keizer and Halman (2007) suggest, 'Radical innovation life cycles are longer, more unpredictable, have more stops and starts, are more context-dependent in that strategic considerations can accelerate, retard or terminate progress, and more often include cross-functional and or cross-unit teamwork. Incremental projects are more linear and predictable, with fewer resource uncertainties, including simpler collaboration relationships' (p. 30). ${ }^{4}$ As with technological risks, market-related risks may also be disproportionately large for micro-enterprises. Larger, mature enterprises are likely to have an established market position which brings with it structural capital, such as supplier and distribution channels, cognitive capital in terms of industry and consumer norms and values and relational capital as reflected in established reputation and trust (DiMaggio and Powell 1991). Mature micro-enterprises are unlikely to have the same stock of structural, cognitive and relational capital as larger firms. This deficit is likely to be greater for younger, or newly established, micro-businesses, increasing the market-related risks of innovation (Hargadon and Douglas 2001).

Innovating through partnering - seeking knowledge and resources outside the firm - may be one way to offset such innovation risks (Carroll 1983). For example, Powell (1998) stresses the potential value of collaboration in reducing risk in the innovation process, accelerating or upgrading the quality of the innovations made and signalling the quality of firms' innovation activities. External innovation linkages may also increase firms' access to external resources and technology developed elsewhere. Further, having more extensive

\footnotetext{
${ }^{3}$ The other predictors of innovation survival identified by Astebro and Michela (2005) are 'technical product maturity' and 'entry cost and price'.

${ }^{4}$ See also Leifer et al. (2000).
} 
networks of external relationships, or more different types of relationships, is likely to increase the probability of obtaining useful knowledge from outside of the firm (Leiponen and Helfat 2010). Empirical evidence also points to the conclusion that knowledge gained from alternative external sources tends to be complementary and also complementary with firms' internal knowledge in shaping innovation performance (Roper et al. 2008). However, as Chesborough (2010) suggests, collaborative innovation poses particular challenges for smaller firms because of their relative lack of capacity to both seek and absorb external knowledge as well as their ability to protect knowledge and appropriate its returns (Laursen and Salter 2014).

The potential importance of innovation partnering for micro-firms suggests the value of considering a model of interactive creative destruction, which retains the creative and destructive dynamics of Schumpeter's original CD model but in which we acknowledge that innovation often occurs through partnerships or collaborations. Partnerships may, for example, enable firms working together to establish joint positions of market dominance or lead to merger or acquisition activity. In either case, the extent, and potentially the nature of firms' innovation collaboration, is likely to be an important determinant of innovation outcomes.

\section{Hypotheses}

Small — and particularly micro-enterprises - are commonly thought to have advantages in terms of flexibility but disadvantages in terms of their resource base (Vossen 1998). There is a substantial literature, however, linking the strength and scale of firms' internal resources positively to innovation. R\&D capacity and investment, for example, have been shown to be important in shaping innovation outcomes in numerous studies (Belderbos et al. 2004; Czarnitzki et al. 2007; Graziadio and Zawislak 1997; Harris and Trainor 1995; Hoffman et al. 1998), as well as contributing to firms' absorptive capacity (Griffith et al. 2003; Xia and Roper 2008). Similarly, firms' investments in intangibles such as design (Filipetti 2010; Fridenson 2009; Marion and Meyer 2011; Moultrie and Livesey 2013), advanced manufacturing technologies (Cardoso et al. 2012; Hewitt-Dundas 2004) and quality improvement (Adam et al. 2001) have also been shown to link strongly to innovation outcomes. Labour quality and training investment have also been linked to stronger innovation outcomes in small firms (Freel 2005; Leiponen 2005). Public support for R\&D and innovation may also create slack within an organisation, allowing greater investments in innovation than would otherwise have been possible (Ballesteros and Rico 2001; Buiseret et al. 1995; Czarnitzki and Licht 2006).

Evidence on the effect of firm size on R\&D investment is mixed, with early work suggesting that larger firms invest more in R\&D (Schumpeter 1942; Arrow 1962) due to the presence of threshold effects, sunk- and fixed-costs and imperfections in capital markets, all of which disadvantage the smaller firm. Empirically, the positive relationship between firm size and R\&D investment has been questioned (for a review see Symeonidis 1996), with some evidence that size effects may be more evident at the early stages of the industry lifecycle (Klepper and Simons 1997). For micro-enterprises, a recent German study found that despite smaller firms being less likely to undertake innovation, for those that do, R\&D intensity increases as firm size decreases. Further, R\&D intensity was found to be positively correlated with the probability of innovating (Baumann and Kritikos 2016).

The evidence therefore suggests that despite constraints on R\&D investments by smaller firms, where R\&D investments do occur, this has a positive effect on innovation outputs and specifically product innovation. Here, we take this a step further and suggest that for micro-firms, investing in $\mathrm{R} \& \mathrm{D}$ will be related to the entry into new markets as opposed to reinforcing existing capabilities and market position through incremental innovation.

\section{Hypothesis 1: Resources}

The probability of micro-enterprises introducing new-to-the-market innovation will increase as their investment in knowledge creation increases.

In addition to their internal resources, previous studies have suggested the importance of external knowledge and resources for innovation outputs (Oerlemans et al. 1998; Love et al. 2014). While it is clear that for micro-firms the process of seeking knowledge outside the firm presents particular problems, recent empirical evidence does, however, suggest that some SMEs do purposively engage in collaborative innovation, and that the prevalence of collaboration among SMEs has increased in recent years (van de Vrande et al. 2009). For 
micro-enterprises seeking to enter new markets and faced with higher relative $R \& D$ costs and risk compared to larger firms, forming external connections may be an efficient strategy to overcoming these constraints. Further, micro-enterprises may be better positioned to access external knowledge and resources (Audretsch and Vivarelli 1996) due to their flexibility in organisational structure and ability to respond quickly to technological and market changes.

At its simplest, the innovation impact of external relationships might depend on a firm's number of connections. Having more connections increases the probability of obtaining useful external knowledge that can be combined with the firm's internal knowledge to produce innovation (Leiponen and Helfat 2010; de Leeuw et al. 2014; Love et al. 2014). The extent or breadth of a firm's portfolio of external connections may also have significant network benefits, reducing the risk of 'lock-in' where firms are either less receptive to knowledge from outside their own region (Boschma 2005), or where firms in a region are highly specialised in certain industries (Camagni 1991). However, the capacity of management to pay attention to, and cognitively process, many sources of information is not infinite particularly in micro-enterprises (Simon 1947). This cognitive constraint means that while the returns to additional connections may at first be positive, eventually, the firm will reach a point at which an additional connection actually diminishes the innovation returns. This is reflected in an extensive empirical literature which suggests an inverted U-shaped relationship between innovation performance and the extent of firms' external networks (Laursen and Salter 2006; Leiponen and Helfat 2010; Grimpe and Sofka 2009; Garriga et al. 2013). Hence,

Hypothesis 2: Co-operation breadth

As the breadth of firms' network of external innovation partners increases, the probability of micro-enterprises introducing new-to-themarket innovation outputs will also increase but with diminishing returns.

Aside from the number and diversity of firms' innovation partnerships, significant attention has focussed on the types of partnerships which impact most directly on innovation. Process innovation in manufacturing, for example, may be most strongly linked to collaboration with universities and suppliers (Un and Asakawa 2015). This suggests the need for firms, and particularly micro-enterprises with limited relationship management capacity and managerial cognition, to adopt a strategic approach to partner choice (Bengtsson et al. 2015). Kohler et al. (2012), in particular, identify those partner types most strongly associated with success in introducing new-to-the-market innovation for a large group of European firms. Their findings suggest that 'science-driven search' with universities and research institutes and 'supplier-driven' search with suppliers are most strongly associated with new-tothe-market innovation. Conversely, 'market-driven' search with customers is most strongly linked to, more imitative, new-to-the-firm innovation. This suggests our final hypothesis that

Hypothesis 3: Exploratory partnerships

Collaboration by micro-enterprises with universities, research institutes or suppliers will result in new-to-the-market innovation.

\section{Data and methods}

\subsection{Data and measures}

Our analysis is based on a survey of innovation among micro-enterprises (with one to nine employees) conducted in Northern Ireland and relating to firms' innovation activity during the 3-year period from 1 January 2010 to 31 December 2012. The survey closely follows the definitions and questions used in the EU Community Innovation Survey and the UK Innovation Survey but uses a different survey methodology being conducted by telephone rather than post. In each firm, the most senior person in the business was the respondent. The survey targeted 1000 businesses, the quota sampled to be representative of the Northern Ireland micro-enterprise population. Of the 1000 respondents, around 240 firms indicated that they had had no need to innovate over the last 3 years due to either prior innovation or the nature of the markets in which they operated. Our analysis focuses on the remaining 761 firms which did identify a need for innovation. Within this group, missing values limit our maximum estimation sample to 735 firms of which 462 were non-innovators, 173 were new-to-the-firm 
innovators only and 100 were new-to-the-market innovators. ${ }^{5}$

Northern Ireland itself is the smallest of the devolved territories of the UK with a population of 1.8 million in 2012 at the time of the survey. ${ }^{6}$ Linked by a land border with the Irish Republic, Northern Ireland has a long history as a centre for heavy engineering and textile manufacture. However, in common with the rest of the UK, significant industrial restructuring has taken place over recent decades with a loss of manufacturing activity and a growth in creative industries and other services. Around 1:6 of the workforce is now employed in manufacturing, with the economy dominated by micro-, small- and medium-sized companies. Labour productivity per hour worked has remained around $79-85 \%$ of the UK average over the 2000-2010 periods and was $17.2 \%$ below the UK average in $2012 .^{7}$

The proportion of firms introducing either new or significantly improved products/services or processes in Northern Ireland and the whole of the UK can be compared using data from the UK Innovation Survey 2013. From 2010 to 2012, $18 \%$ of UK firms introduced new products or services compared to $14.6 \%$ in Northern Ireland. A more significant difference was evident between the proportion of revenue derived from new-tothe-market innovation in the UK $(7.5 \%)$ and Northern Ireland (3.2\%). Conversely, Northern Ireland firms derived $12.4 \%$ of revenues from new-to-the-firm innovations compared to $10.7 \%$ in the UK. ${ }^{8}$ Product innovators in Northern Ireland (52.1\%) were also less likely to be collaborating with other partners than similar firms in the UK (62.7\%). Possible explanations for this relatively low level of collaborative innovation activity in Northern Ireland are suggested by previous analyses of Northern Ireland's innovation capabilities. One study of

\footnotetext{
$\overline{5}$ The sectoral coverage of the estimation sample was as follows in terms of SIC $2007(n=735)$ : SIC 15-33 manufacturing 7.48\%; SIC 41-43 construction, $19.73 \%$; SIC 45-46 wholesale trade, $12.93 \%$; SIC 47 retail trade, $13.61 \%$; SIC 49-53, 61 transport, storage, $3.95 \%$; SIC $55-56$ hotels and restaurants, $6.8 \%$; SIC 58, 62, 63, 68-82 real estate, $29.93 \%$; all other sectors, $5.57 \%$.

${ }^{6}$ Source: Region and Country Profiles-Population and Migration, Office of National Statistics, 30 May 2012.

${ }^{7}$ Source: Region and Country Profiles: Economy, Office of National Statistics, 30 May 2012. Regional Economic Indicators, July 2014, ONS.

${ }^{8}$ Source: UK Innovation Survey 2010 to 2012: annex. Available at: https://www.gov.uk/government/statistics/uk-innovation-survey-2013statistical-annex
}

absorptive capacity, for example, places Northern Ireland below the UK average on each of the dimensions measured (NESTA 2008). Another recent study of the innovation systems of Northern Ireland and Ireland also suggests that "Despite numerous agents and supports available to support collaboration and networking, it would appear that the full breadth of the ecosystem is not being fully exploited either at local level or beyond and opportunities exist to increase the relevance of and connections to the other innovation partners". 9 In terms of the ICD framework outlined earlier, this suggests that the potential for collaborative innovation in Northern Ireland may be under-developed at present, perhaps accounting for the lower than average level of new-tomarket innovation.

Consistent with the ICD model, our interest here is in what shapes micro-enterprises' ability to introduce new-to-the-market products or services. In the micro-enterprise survey, this is reflected in a binary indicator of whether or not firms introduced new-tothe-market products or services over the 2010 to 2012 period. While this type of innovation is clearly important in driving the type of competitive process envisaged in the ICD model, three caveats relating to this measure are worth highlighting. First, the measure is subjective in the sense that it relies on micro-enterprises' own judgement of what is and what is not new-to-the-market innovation. It is difficult to be clear about the scale of any likely bias in this measure, but the probability is that this overstates the proportion of innovations described as new to the market. In this context, it is interesting that in the micro-business survey, $13.7 \%$ of firms reported introducing new-to-the-market innovations in our estimation sample (Table 1, Annex 1) compared to only $7.9 \%$ in the UK Innovation Survey which provides representative figures for all UK businesses. ${ }^{10}$ Second, the question arises of which market the innovation is new to. For the majority of micro-enterprises in the sample, this is the UK and Irish market as only $5.9 \%$ of micro-businesses were

\footnotetext{
${ }^{9}$ See IntertradeIreland (2012) Leveraging the innovation ecosystem for business advantage: a cross border study, October 2012.

${ }^{10}$ As the original survey report makes clear, however, "higher [microbusiness] innovation rates compared to the UKIS... are a likely consequence of differences in survey methodology. For example, respondents are the most senior person in the business and therefore more likely both to be aware of, and recall, innovation-related activity'.
} 
Table 1 Sample descriptives

\begin{tabular}{|c|c|c|c|}
\hline & Obs & Mean & $\begin{array}{l}\text { Std. } \\
\text { Dev. }\end{array}$ \\
\hline \multicolumn{4}{|l|}{ Innovation measures } \\
\hline New-to-the-firm innovation ( $\%$ firms) & 735 & 0.371 & 0.484 \\
\hline $\begin{array}{l}\text { New-to-the-market innovation } \\
\text { (\% firms) }\end{array}$ & 732 & 0.137 & 0.344 \\
\hline Innovation sophistication (avg. scale) & 735 & 0.507 & 0.723 \\
\hline \multicolumn{4}{|l|}{ Resources } \\
\hline R\&D active firm (\% firms) & 735 & 0.227 & 0.419 \\
\hline $\begin{array}{l}\text { Types of innovation investment } \\
\text { (avg. scale) }\end{array}$ & 735 & 2.307 & 1.602 \\
\hline Public support for innovation (\% firms) & 735 & 0.067 & 0.250 \\
\hline \multicolumn{4}{|l|}{ Co-operation } \\
\hline Breadth of co-operation (avg. number) & 735 & 0.873 & 1.531 \\
\hline $\begin{array}{l}\text { Science-based co-operation } \\
\text { (avg. number) }\end{array}$ & 735 & 0.116 & 0.393 \\
\hline $\begin{array}{l}\text { Supplier-based co-operation } \\
\text { (avg. number) }\end{array}$ & 735 & 0.280 & 0.545 \\
\hline $\begin{array}{l}\text { Market-based co-operation } \\
\text { (avg. number) }\end{array}$ & 735 & 0.478 & 0.890 \\
\hline \multicolumn{4}{|l|}{ Control variables } \\
\hline Family business ( $\%$ firms) & 735 & 0.810 & 0.393 \\
\hline Share female directors ( $\%$ firms) & 735 & 25.278 & 37.956 \\
\hline O-M has STEM background (\%) & 735 & 0.265 & 0.442 \\
\hline $\mathrm{O}-\mathrm{M}$ is graduate $(\%)$ & 735 & 0.486 & 0.500 \\
\hline Employment in firm (2010) & 735 & 3.912 & 2.139 \\
\hline Independent business ( $\%$ firms) & 735 & 0.909 & 0.288 \\
\hline Age of business (years) & 735 & 20.487 & 18.903 \\
\hline $\begin{array}{l}\text { Selling outside UK and Ireland } \\
\text { (\% firms) }\end{array}$ & 735 & 0.059 & 0.235 \\
\hline
\end{tabular}

Source: Survey of micro-businesses in Northern Ireland, 2014

exporting. Third, the binary indicator provided gives us little idea of the commercial success of the innovation itself. In the UK Innovation Survey, for example, and other EU Community Innovation Surveys, firms are asked what proportion of their sales are derived from new-to-the-market innovation; however, this question was not asked in the microenterprise survey.

To address our first hypothesis, we measure the resources available for micro-enterprises' innovation activity using three indicators. First, we include a binary variable to reflect the engagement of the business in $\mathrm{R} \& \mathrm{D}$, which is generally associated positively with new product development (Roper and Hewitt-Dundas 2015). Second, we include a variable to reflect micro- enterprises' investment in other aspects of innovation such as design, training for innovation etc. ${ }^{11} \mathrm{We}$ anticipate this variable having a positive impact on innovation given evidence from other studies that, for example, investments in design and machinery are associated with higher innovation outputs (Marsili and Salter 2006). Third, we include a variable indicating whether or not the micro-enterprise received public support from local, national or supranational agencies to support its innovation activity. Such support has been shown in the past to be positively linked to innovation outputs (Smith 1989; Hewitt-Dundas and Roper 2009; Gongora et al. 2010).

To address our second and third hypotheses, we measure the extent of micro-enterprises' external cooperation for innovation using two different approaches. First, we use the now standard measure of the 'breadth' of firms' set of innovation linkages (Laursen and Salter 2006). This relates to the number of partner types with which a firm is engaging whether those partners are local, national or international. In the survey, seven different partner types are identified and this variable therefore takes values 0 to $7 .^{12}$ Previous studies have highlighted an inverted-U-shaped relationship between this measure and innovation outputs, and we therefore include a square of this variable in all models to capture the potential for this non-linear effect (Vahter et al. 2014). Second, to capture the innovation value of different types of linkage, we split the overall breadth of firms' innovation co-operation into three sub-categories: science-driven links involving commercial labs or private $R \& D$ institutes, universities and government or public research institutes; market-driven links to customers from the private sector and public sectors and supplier-driven links to suppliers of equipment,

\footnotetext{
${ }^{11}$ Ten types of innovation investment are identified in the microbusiness questionnaire. This variable therefore takes values between 0 and 10 . The options were as follows: advanced machinery and equipment; computer hardware; computer software; purchase of licensing of patents and non-patented inventions, know-how and other types of knowledge from other businesses or organisations; internal or external training for your personnel, specifically for the development andlor introduction of innovations; engagement in all design activities, including strategic, for the development or implementation of new or improved goods, services and processes; changes to product or service design; market research; changes to marketing methods; launch advertising.

12 These are suppliers of equipment, materials, services or software; clients or customers from the private sector; clients or customers from the public sector; competitors or other businesses in your industry; consultants, commercial labs or private R\&D institutes; universities or other higher education institutions and government or public research institutes.
} 
competitors and consultants. Our division of overall search breadth into these three components is suggested by the analysis of Kohler et al. (2012).

We also include in our estimation a number of firmlevel control variables which previous studies have linked to innovation outputs. First, we include variables related to whether or not the owner-manager of the firm has a science or technology background and whether she or he is a graduate. Both we anticipate will be positively related to innovation. Employment in the firm is also included which again we expect to be positively related to innovation. Second, an indicator of the independence of the firm is also included to reflect any potential resource advantage accruing to firms which are group members (Choi et al. 2012). Third, firm age is included to capture any accumulated resource advantages (Balasubramanian and Lee 2008). Fourth, we include an exporting variable to capture any benefit which firms derive from selling in international markets (Love and Roper 2015). Fifth, we include a binary variable to indicate whether firms are family owned. ${ }^{13}$ Previous studies have suggested that family firms may be more risk averse, keener on preserving wealth rather than undertaking the type of risky investments implicit in new-to-the-market innovation (Kotlar et al. 2014; Matzler et al. 2015; Sciascia et al. 2015). ${ }^{14}$ Overall, $81.0 \%$ of micro-enterprises in our estimation sample indicated that the business was family owned (Table 1). Finally we, include an indicator to capture any 'value of diversity' associated with a more diverse workforce (Diaz-Garcia et al. 2013) ${ }^{15}$ following Ostergaard et al. (2011) and include both the proportion of female owners, partners and directors and a squared term to allow for any non-linear effects of gender balance.

\footnotetext{
${ }^{13}$ The categorisation of businesses as family owned and controlled has received substantial attention in the research literature and generated significant debate. In the current context, we are limited to a single question in the micro-enterprise survey which directly asked, 'Is the business family-owned?' and required a binary response. We have no information in the survey on whether a business is both family owned and family run.

${ }^{14}$ Although see Craig et al. (2014), who find no significant differences in the propensity to take risks among a large sample of Finnish family and non-family firms.

${ }^{15}$ In the survey, micro-enterprises were asked how many 'owners, partners and directors were there in day-to-day control of the business' and then 'how many of these owners, partners and directors (OPDs) were female?' On average, around a quarter of all OPDs were female (Table 1), a figure strongly consistent with other studies of UK businesses (Martin et al. 2008).
}

\subsection{Analytical approach}

Our analysis is based on the concept of the innovation production function, which relates micro-enterprises' innovation outputs to the knowledge inputs to their innovation process (Griliches 1995; Love and Roper 2001; Laursen and Salter 2006). Adopting the innovation production function also allows us to take into account firm characteristics and other elements of micro-enterprises' innovation strategies, e.g. investments in R\&D, design and innovation partnerships, alongside firms' ownership and leadership profile. Furthermore, it enables us to identify any contingent factors, which might be associated with aspects of firms' operating environment (e.g. sector) or other dimensions of firms' innovation activity (e.g. size). We investigate two different forms of the innovation production function relating to the different hypotheses. Let $I O_{i}$ be an indicator of the probability that a micro-business will be doing new-to-the-market innovation, and then to investigate hypotheses 1 and 2, we estimate

$$
\begin{aligned}
I O_{i}= & \alpha+\beta_{0} R_{E S}+\beta_{1} X T_{i}+\beta_{2} X T_{i} * X T_{i} \\
& +\beta_{3} \operatorname{CONT}_{i}+\varepsilon_{i}
\end{aligned}
$$

where $R E S_{i}$ is a vector of resource indicators, $X T_{i}$ are the number of external connections and $C O N T_{i}$ is a series of firm-level controls. Hypothesis 1 requires that $\beta_{0}>0$; hypothesis 2 requires that $\beta_{1}>0$ and $\beta_{2}<0$.

To investigate the value of different types of external linkages for new-to-the-market activity-hypothesis 3 -we divide firms' external linkages into those relating to the science-base $\left(X T S C_{i}\right)$, those to suppliers $\left(X T S U_{i}\right)$ and those to other market-based partners $\left(X T M B_{i}\right)$. This implies

$$
\begin{aligned}
I O_{i}= & \alpha+\beta_{0} R_{E S}+\beta_{1} \mathrm{XTSC}_{i}+\beta_{2} \mathrm{XTSU}_{i} \\
& +\beta_{3} \mathrm{XTMB}_{i}+\beta_{4} X T_{i}+\beta_{5} \mathrm{CONT}_{i}+\varepsilon_{i}
\end{aligned}
$$

where hypothesis 3 requires that $\beta_{1}>0, \beta_{2}>0$ and $\beta_{3}=0$.

We use two different modelling approaches to explore each hypothesis. The first reports a series of bivariate probit models focussed on the probability that micro-enterprises will make new-to-themarket innovations. For comparison, we also report models for the probability of undertaking new-tothe-firm innovation. Second, we use ordered probit 
models reflecting the progression from no innovation, through new-to-the-firm innovation to new-tothe-market innovation. The results from each estimation approach prove very similar.

\section{Empirical results}

We report probit models for the probability that firms will undertake new-to-the-firm innovation in Table 2. In addition to the variables of interest and the controls, all models include sectoral dummies at the two-digit level. In each case, the reference group is the group of 462 non-innovating firms, i.e. the models for new-to-the-market innovation exclude those (173) firms doing only new-to-thefirm innovation. ${ }^{16}$ Models (2), (4) and (6) relate to new-to-the-market innovation and, for comparison, models (1), (3) and (5) relate to new-to-the-firm innovation in products or services. The first two models in the table include only control variables. Model fit improves significantly when the main independent variables are added. Average VIF statistics are 3.41 for models (5) and (6), which are well below the conventional cut-off (10) for serious multi-collinearity.

Hypothesis 1 suggests a positive link between firms' resources and their probability of undertaking new-to-the-market innovation. This is supported in the case of R\&D activity and innovation investment but, contrary to other studies of larger firms, we find no evidence that public support for innovation has any positive output effect. Indeed, R\&D itself only has a significant association with new-to-the-market innovation but no significant link to new-to-the-firm innovation. It is also notable that the marginal coefficient on other types of innovation investment (i.e. design, market research, IT etc.) is more than twice that for new-to-the-firm innovation than new-to-themarket (Table 2). This suggests the rather different nature of the investments underlying new-to-thefirm and new-to-the-market innovation, with the

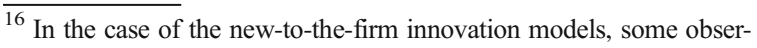
vations were also dropped due to sectoral dummies being perfectly correlated with the dependent variable. This reduced the estimation sample from a possible 562 (462 non-innovators and 100 new-to-themarket innovators) to 547.
}

former relying more heavily on externally acquired knowledge or expertise and new-to-the-market innovation with its higher degree of novelty linked more strongly to in-house R\&D activity. For example, licensed-in technology previously used elsewhere would require an investment by the firm and may lead only to a new-to-the-firm innovation. R\&D investments are likely to be linked to more exploratory activity helping firms to introduce more novel new-to-the-market innovations.

Central to the notion of the ICD model is interorganisational co-operation, and hypothesis 2 argues that the breadth of firms' co-operation will be important for new-to-the-market innovation. In the estimated models, we include both a level and quadratic term to reflect earlier studies of an inverted-Ushaped relationship between the breadth of firms' co-operation and innovation outputs. This resolves to a single marginal effect (measured at variable means) for the relationship between breadth and innovation outputs which is positive and significant in each model (Table 2). This provides strong support for hypothesis 2. Estimates of the marginal effects of co-operation on innovation at different levels of breadth where all other variables are held at variable means are included in Fig. 1. The marginal benefits of extending co-operation are clearly strongest for micro-firms' first two connections and then fall-particularly for new-to-the-firm innovation - as the number of connections increases beyond this. Negative marginal effects where breadth is largest suggest the normal inverted-U-shaped relationship which characterises the contribution of external connectivity to innovative outputs (Fig. 1). Notably, these negative marginal returns are encountered at lower levels of breadth for new-to-the-firm innovation than for the potentially more complex new-to-the-market innovation (Fig. 1). Overall, our results provide strong support for hypothesis 2 , and the importance of external collaboration for new-tothe-market innovation. As a robustness check on this result, we also investigated potential absorptive capacity effects, interacting our measure of connectivity with $R \& D$ and the control variable indicating whether the owner-manager of the business was a graduate. The external connectivity effects remain the same with neither interaction measure proving significant for either new-to-the-market or new-tothe-firm innovation. 


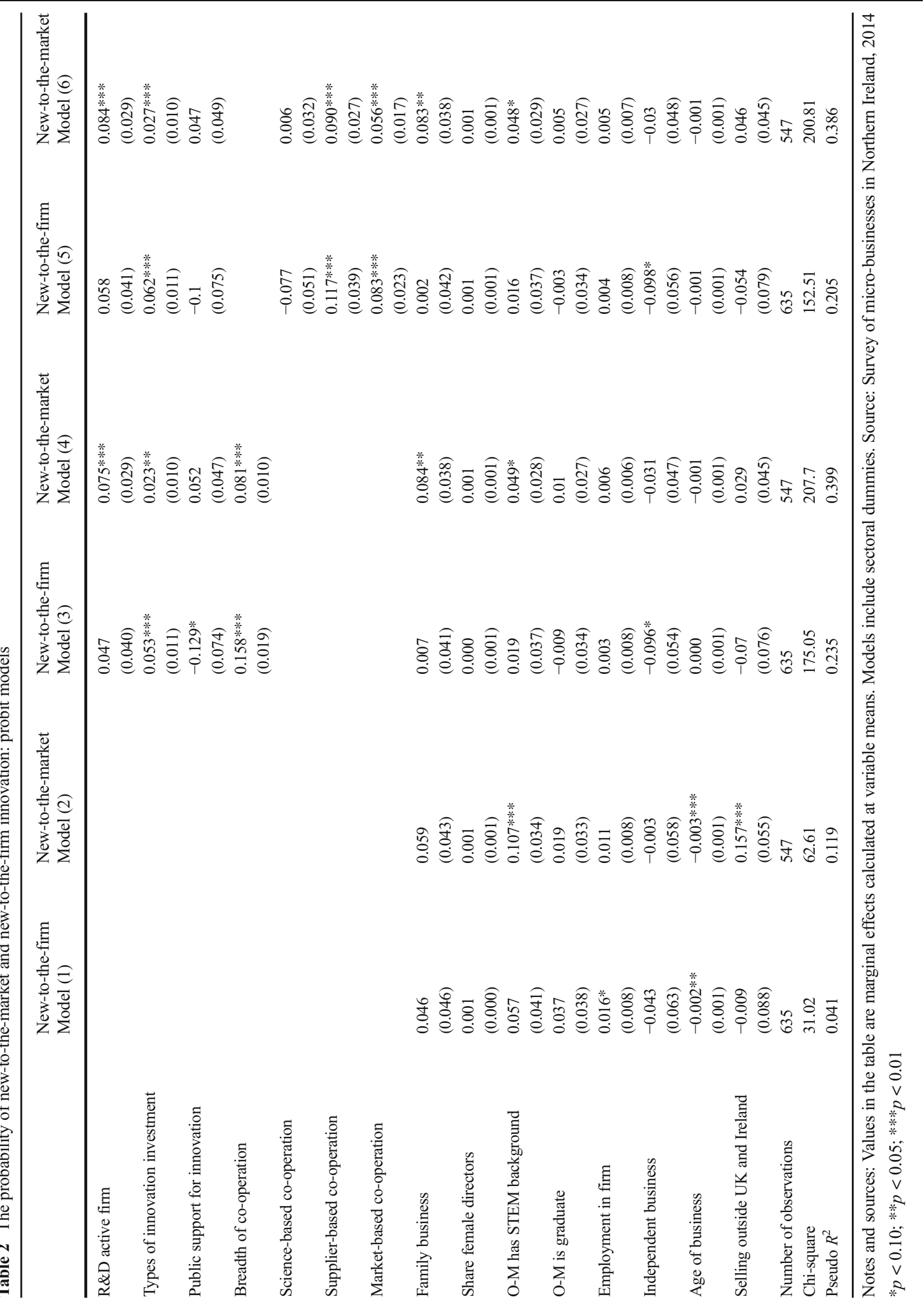




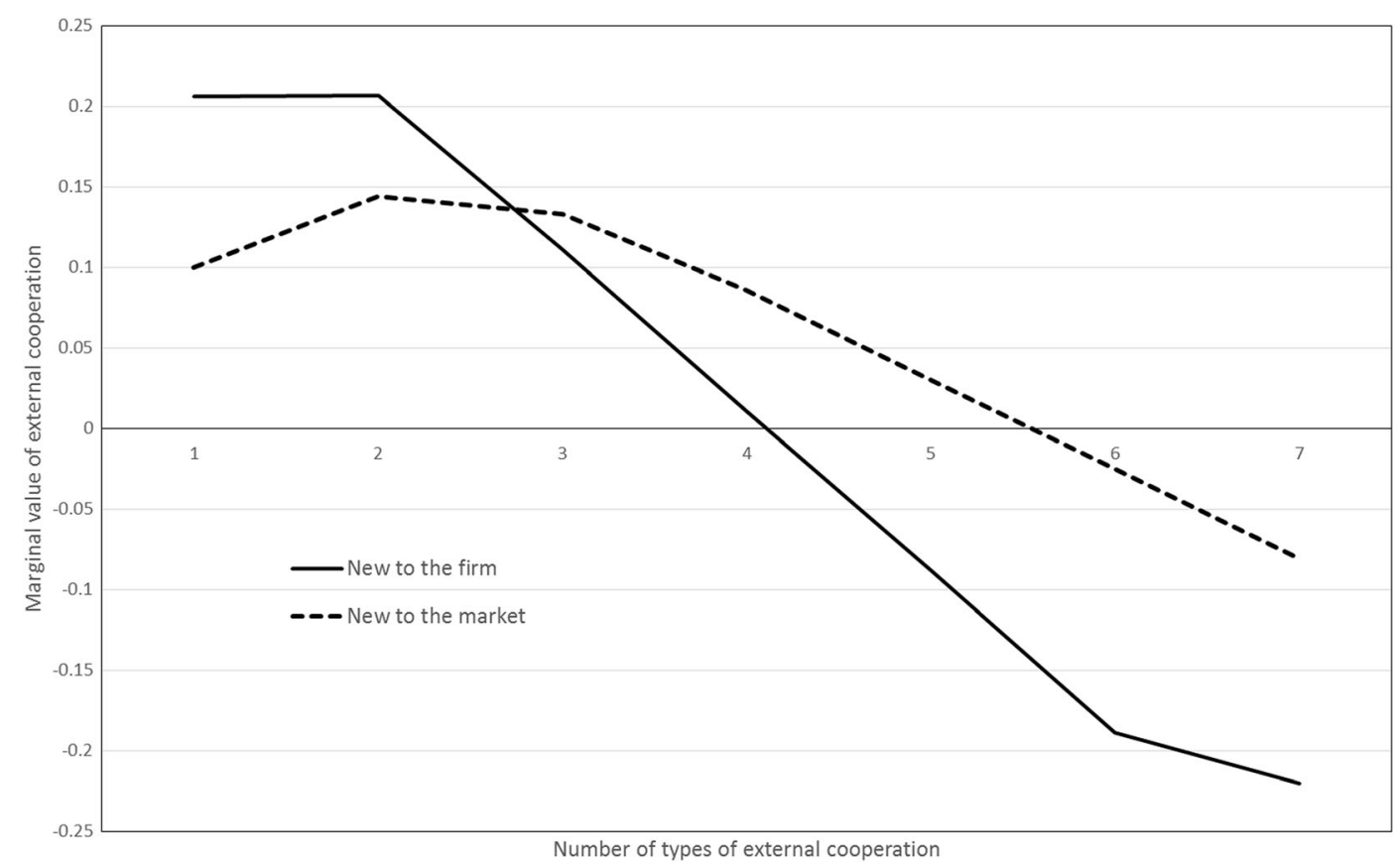

Fig. 1 Marginal effects of the breadth of external co-operation on innovation outputs

Our final hypothesis relates to the nature of micro-enterprises' innovation collaboration and suggests that links to suppliers, universities and research institutes are most likely to be associated with new-to-the-market innovation (Kohler et al. 2012). We find only partial support for this hypothesis, with both supplier-based co-operation and market-based co-operation having beneficial effects for both new-to-the-firm and new-to-the-market innovations. Unlike Kohler et al. (2012), we find no positive association between science-based co-operation - with universities or research laboratoriesand new-to-the-market innovation. It is possible that this may reflect either the paucity of links between micro-enterprises and universities or the more limited absorptive capacity of micro-businesses. Including interaction effects with $R \& D$ in these models to test this idea changes little, with the interaction effects largely insignificant. Where a firms' ownermanager is a graduate, there is, however, a positive interaction effect with science-based co-operation for both new-to-the-market and new-to-the-firm innovation. Graduate status has no significant interaction with either supplier or market-based collaboration. This perhaps suggests the specificity of absorptive capacity required for different types of external collaboration (Schmidt 2010).

Our control variables largely take the anticipated signs. One notable exception is the unanticipated positive effect of family ownership on new-to-themarket innovation: family-owned firms are 8.3$8.4 \%$ more likely to introduce new-to-the-market innovations than are non-family-owned firms. This suggests that the long-term perspective and patient capital of family-owned firms outweighs any greater risk aversion among family-owned firms (Matzler et al. 2015; Sciascia et al. 2015). Interestingly, this effect is only evident for new-to-the-market innovation with no significant family ownership effect for more incremental product or service change.

In Table 3, partly as a robustness check, we report ordered probit models estimated across the whole group of non-innovators, new-to-the-firm and newto-the-market innovators. Table 4 reports the marginal values for the two ordered probit models. The ordered probit models largely re-emphasise the importance of those variables identified earlier: $R \& D$ and innovation investment are important as is external supplier-based and market-based co-operation (Table 3). There is again evidence of a significant 
Table 3 Modelling the complexity of new goods and services: ordered probit models

\begin{tabular}{|c|c|c|}
\hline & Model 1 & Model 2 \\
\hline R\&D active firm & $\begin{array}{l}0.386 * * * \\
(0.119)\end{array}$ & $\begin{array}{l}0.407 * * * \\
(0.119)\end{array}$ \\
\hline Types of innovation investment & $\begin{array}{l}0.185 * * * \\
(0.038)\end{array}$ & $\begin{array}{l}0.197 \text { *** } \\
(0.038)\end{array}$ \\
\hline Public support for innovation & $\begin{array}{l}0.162 \\
(0.203)\end{array}$ & $\begin{array}{l}0.111 \\
(0.207)\end{array}$ \\
\hline Breadth of co-operation & $\begin{array}{l}0.663 * * * \\
(0.085)\end{array}$ & \\
\hline Breadth of co-operation squared & $\begin{array}{l}-0.083 * * * \\
(0.017)\end{array}$ & \\
\hline Science-based co-operation & & $\begin{array}{l}-0.05 \\
(0.133)\end{array}$ \\
\hline Supplier-based co-operation & & $\begin{array}{l}0.491 \text { *** } \\
(0.110)\end{array}$ \\
\hline Market-based co-operation & & $\begin{array}{l}0.265^{* * *} \\
(0.066)\end{array}$ \\
\hline Family business & $\begin{array}{l}0.241 * \\
(0.136)\end{array}$ & $\begin{array}{l}0.251 * \\
(0.135)\end{array}$ \\
\hline Share female directors & $\begin{array}{l}0.005 \\
(0.005)\end{array}$ & $\begin{array}{l}0.005 \\
(0.005)\end{array}$ \\
\hline Share female directors — squared & $\begin{array}{l}-0.003 \\
(0.005)\end{array}$ & $\begin{array}{l}-0.003 \\
(0.005)\end{array}$ \\
\hline O-M has STEM background & $\begin{array}{l}0.136 \\
(0.116)\end{array}$ & $\begin{array}{l}0.14 \\
(0.116)\end{array}$ \\
\hline $\mathrm{O}-\mathrm{M}$ is graduate & $\begin{array}{l}-0.035 \\
(0.109)\end{array}$ & $\begin{array}{l}-0.025 \\
(0.109)\end{array}$ \\
\hline Employment in firm & $\begin{array}{l}0.027 \\
(0.025)\end{array}$ & $\begin{array}{l}0.027 \\
(0.025)\end{array}$ \\
\hline Independent business & $\begin{array}{l}-0.313^{*} \\
(0.179)\end{array}$ & $\begin{array}{l}-0.288 \\
(0.179)\end{array}$ \\
\hline Age of business & $\begin{array}{l}-0.002 \\
(0.003)\end{array}$ & $\begin{array}{l}-0.004 \\
(0.003)\end{array}$ \\
\hline Selling outside UK and Ireland & $\begin{array}{l}0.169 \\
(0.208)\end{array}$ & $\begin{array}{l}0.222 \\
(0.207)\end{array}$ \\
\hline Split-no innovation to $n-t-f$ innovation & $\begin{array}{l}1.517 \\
(0.995)\end{array}$ & $\begin{array}{l}1.519 \\
(0.996)\end{array}$ \\
\hline Split-n-t-f to $n-t-m$ innovation & $\begin{array}{l}2.582 * * * \\
(0.998)\end{array}$ & $\begin{array}{l}2.566^{* *} \\
(0.998)\end{array}$ \\
\hline Number of observations & 735 & 735 \\
\hline Chi-square & 296.407 & 280.28 \\
\hline Pseudo $R^{2}$ & 0.223 & 0.211 \\
\hline $\mathrm{Bic}$ & 1230.064 & 1252.791 \\
\hline
\end{tabular}

Notes and sources: Models include sectoral dummies. Source: Survey of micro-businesses in Northern Ireland, 2014

$* p<0.10 ; * * p<0.05 ; * * * p<0.01$ family ownership effect linked to the greater novelty of innovation activity (Table 3). The marginal values are confirmatory, suggesting, for example, that firms are less likely to be in the non-innovator group when they are R\&D active and more likely to be in either the new-to-the-firm or new-to-the-market groups. As we might anticipate, the marginal effects of $\mathrm{R} \& \mathrm{D}$, innovation investment and co-operation activity are largest for new-to-the-market innovation (Table 4).

\section{Discussion}

Our conceptual discussion focuses on the potential role of co-operation or interaction in driving new-tothe-market innovation-and hence a creative destruction process-among micro-enterprises. We find strong support for this central proposition, particularly in terms of supplier and market-based cooperation, and for the important role of other types of innovation investment and R\&D in shaping the probability of new-to-the-market innovation (Table 2). These inputs to the innovation process may be playing complementary roles, with firms' in-house R\&D capabilities helping to identify and perhaps absorb externally acquired knowledge (Cohen and Levinthal 1989). This confirms previous empirical findings that $R \& D$ is positively correlated with innovation activity in micro-enterprises (Baumann and Kritikos 2016). Yet, our findings refine this further with $R \& D$ investment in microenterprises positively associated with the new-tothe-market innovation and not new-to-the-firm innovation. Innovation investments may also be playing a complementary role, providing an alternative to co-operation for accessing externally available knowledge. We also find some evidence that family businesses are more likely to introduce new-to-themarket innovation.

How does the importance of innovation cooperation suggested by our empirical analysis, and the role of firms' internal complementary knowledge assets, change the competitive dynamics of the $\mathrm{CD}$ model among micro-enterprises? In the rather specific context of pharmaceuticals, for example, Rothaermel (2001) shows that incumbents derive performance benefits from developing alliances with new technology providers in a process 
Table 4 Modelling the complexity of new goods and services: marginal values from ordered probit models

\begin{tabular}{|c|c|c|c|c|c|c|}
\hline & \multicolumn{2}{|c|}{ Base level—no innov. } & \multicolumn{2}{|c|}{ New-to-the-firm } & \multicolumn{2}{|c|}{ New-to-the-market } \\
\hline & $\mathrm{dy} / \mathrm{dx}$ & Std. Err. & $\mathrm{dy} / \mathrm{dx}$ & Std. Err. & $\mathrm{dy} / \mathrm{dx}$ & Std. Err. \\
\hline \multicolumn{7}{|c|}{ A. Marginal values for model 1 in Table 3} \\
\hline $\mathrm{R} \& \mathrm{D}$ active firm & -0.106 & $(0.032)^{* * *}$ & 0.047 & $(0.015)^{* * *}$ & 0.059 & $(0.018)^{* * *}$ \\
\hline Types of innovation investment & -0.051 & $(0.010)^{* * *}$ & 0.022 & $(0.005)^{* * *}$ & 0.028 & $(0.006)^{* * *}$ \\
\hline Public support for innovation & -0.044 & $(0.056)$ & 0.020 & $(0.025)$ & 0.025 & $(0.031)$ \\
\hline Breadth of co-operation & -0.141 & $(0.015)^{* * *}$ & 0.088 & $(0.012)^{* * *}$ & 0.052 & $(0.006)^{* * *}$ \\
\hline Family business & -0.066 & $(0.037)^{* *}$ & 0.029 & $(0.017)^{* *}$ & 0.037 & $(0.021)^{* *}$ \\
\hline Share female directors & -0.001 & $(0.001)$ & 0.000 & $(0.000)$ & 0.000 & $(0.000)$ \\
\hline O-M has STEM background & -0.037 & $(0.032)$ & 0.016 & $(0.014)$ & 0.021 & $(0.018)$ \\
\hline $\mathrm{O}-\mathrm{M}$ is graduate & 0.010 & $(0.030)$ & -0.004 & $(0.013)$ & -0.005 & $(0.017)$ \\
\hline Employment in firm & -0.007 & $(0.007)$ & 0.003 & $(0.003)$ & 0.004 & $(0.004)$ \\
\hline Independent business & 0.086 & $(0.049)^{* *}$ & -0.038 & $(0.022)^{* *}$ & -0.048 & $(0.027)^{* *}$ \\
\hline Age of business & 0.001 & $(0.001)$ & 0.000 & $(0.000)$ & 0.000 & $(0.000)$ \\
\hline Selling outside UK and Ireland & -0.046 & $(0.057)$ & 0.020 & $(0.025)$ & 0.026 & $(0.032)$ \\
\hline \multicolumn{7}{|c|}{ B. Marginal values for model 2 in Table 3} \\
\hline R\&D active firm & -0.115 & $(0.033)^{* * *}$ & 0.053 & $(0.016)^{* * *}$ & 0.062 & $(0.018)^{* * * *}$ \\
\hline Types of innovation investment & -0.056 & $(0.010)^{* * *}$ & 0.026 & $(0.005)^{* * *}$ & 0.030 & $(0.006)^{* * *}$ \\
\hline Public support for innovation & -0.031 & $(0.058)$ & 0.015 & $(0.027)$ & 0.017 & $(0.031)$ \\
\hline Science-based co-operation & 0.014 & $(0.038)$ & -0.006 & $(0.017)$ & -0.008 & $(0.020)$ \\
\hline Supplier-based co-operation & -0.139 & $(0.030)^{* * *}$ & 0.064 & $(0.015)^{* * *}$ & 0.075 & $(0.016)^{* * *}$ \\
\hline Market-based co-operation & -0.075 & $(0.018)^{* * *}$ & 0.035 & $(0.009)^{* * *}$ & 0.040 & $(0.010)^{* * * *}$ \\
\hline Family business & -0.071 & $(0.038)^{* *}$ & 0.033 & $(0.018)^{* *}$ & 0.038 & $(0.021)^{* *}$ \\
\hline Share female directors & -0.000 & $(0.000)$ & 0.000 & $(0.000)$ & 0.000 & $(0.000)$ \\
\hline O-M has STEM background & -0.040 & $(0.033)$ & 0.018 & $(0.015)$ & 0.021 & $(0.018)$ \\
\hline $\mathrm{O}-\mathrm{M}$ is graduate & 0.007 & $(0.031)$ & -0.003 & $(0.014)$ & -0.004 & $(0.017)$ \\
\hline Employment in firm & -0.007 & $(0.007)$ & 0.003 & $(0.003)$ & 0.004 & $(0.004)$ \\
\hline Independent business & 0.081 & $(0.050)$ & -0.038 & $(0.023)$ & -0.044 & $(0.027)$ \\
\hline Age of business & 0.001 & $(0.001)$ & 0.000 & $(0.000)$ & -0.001 & $(0.000)$ \\
\hline Selling outside UK and Ireland & 0.000 & $(0.000)$ & 0.029 & $(0.027)$ & 0.034 & $(0.031)$ \\
\hline
\end{tabular}

Notes and sources: Values in the table are marginal effects calculated at variable means derived from the models in Table 3. Source: Survey of micro-businesses in Northern Ireland, 2014

$* p<0.10 ; * * p<0.05 ; p<0.01$

which is mutually beneficial: through alliance formation, the incumbent neutralises any competitive threat from the new entrant at the cost of internalising any commercial or technical risk; the new entrant benefits from the resource advantages and market legitimacy of the incumbent. This is especially advantageous for micro-enterprises where $R \& D$ investment is more difficult (Conte and Vivarelli 2014), and new market entry is hindered by issues of legitimacy. Where industries are more atomistic, these strategic advantages to both parties - incumbents and new entrants - will be less pronounced, and motivations for alliance or partnership may instead emphasise resource acquisition and/or risk mitigation. This may influence both firms' alliance portfolios and strategy in terms of each individual partnership. There is mounting evidence, for example, that for smaller firms, the breadth of firms' alliance portfolios contributes both to innovative outputs and organisational performance albeit with a declining marginal benefit for each added partner type (Beck and Schenker- 
Wicki 2014; Vahter et al. 2014). Alongside the technological leadership capabilities required for success in the traditional CD model, the need for small firms to carefully select partners also emphasises the importance of firms' organisational capabilities around partner search, partnership management and learning capabilities (Love et al. 2014; Zhu 2006). This links into on-going debates about ambidexterity in innovation and firms' ability to effectively explore and develop new technologies through partnerships and then effectively exploit the innovations developed (Chang and Hughes 2012).

The implication is that to be successful in the ICD model, micro-enterprises require a rather different - and broader-profile of internal capabilities than in a more traditional $C D$ setting. In the $C D$ model, internal innovation dominates and the emphasis is on firms' internal ambidexterity - their ability to develop and effectively exploit technological innovation based on their internal resources, typically R\&D investment. In the ICD model, the picture is more complex with firms needing to achieve partnership ambidexterity_developing relationships which effectively combine internal and external resources to achieve technological leadership (Tiwana 2008). This is emphasised in our analysis by the simultaneous importance of what are potentially exploratory relationships to suppliers and potentially exploitative relationships to customers.

The importance of co-operation in driving newto-the-market innovation in micro-enterprises may also contradict to some extent the fluid competitive dynamics of the CD model with its emphasis on the temporary technological leadership of individual firms. Instead, as Rahman and Korn (2014, 257) suggest, 'many promising alliances fail to produce satisfactory results because of their inadequate longevity ... greater longevity may translate to more time to work on the alliance to yield satisfactory results'. On the other hand, alliances of longer duration may allow the development of deeper, more complementary, relationships between firms yielding more positive outcomes (Pangarkar 2003). In the ICD model. this suggests two possible innovation strategies for micro-enterprises seeking to introduce new-to-the-market innovation-that of closed or solo innovation and that of collaborative innovation. Interestingly, in our sample of microenterprises, the latter strategy predominates with $74.8 \%$ of new-to-the-market innovators collaborating with (often multiple) external partners and only $25.2 \%$ being solo innovators. Moreover, new-to-themarket innovators were typically working with 2.8 types of partner compared to 0.99 among all firms in the estimation sample.

Alongside collaboration, our analysis also highlights the positive role of family ownership on micro-enterprises' introduction of new-to-themarket innovation (Table 2). On first sight, this result appears to contradict the majority of existing evidence which suggests a negative relationship between family ownership and R\&D investment (Matzler et al. 2015; Sciascia et al. 2015), although our results are similar to those of a recent German study linking family ownership positively to innovation outputs (Matzler et al. 2015). One possibility consistent with both this wider evidence and our analysis would be that family firms have higher levels of external collaboration and are therefore able to economise on internal $R \& D$ expenditure. In our sample, however, among new-to-the-market innovators, levels of external collaboration are actually lower among family-owned firms (an average of 2.57 external partner types) than among nonfamily-owned firms (3.9 partner types on average). This is consistent with evidence from other studies which suggests that in order to preserve control over their innovation activities, family-owned firms are reluctant to engage in innovation partnerships (Kotlar et al. 2014). More persuasive therefore are arguments which suggest that, all else being equal, family-owned firms may be more effective innovators due to deeply embedded knowledge of the company and its operation, close relations between family members and shared business objectives (Chrisman et al. 2012). It may also be the case that these attributes reduce the search costs of external relationships and enhance the contribution of such relationships to family-owned firms' innovation outputs.

In managerial terms, our study emphasises the range of capabilities necessary for micro-enterprises to undertake new-to-the-market innovation and so contribute to the CD process. Managerial attitudes, resource coordination, appropriability strategies and partnering skills may be equally important as more technological competencies 
(Laursen and Salter 2014), although our results do suggest that new-to-the-market innovation is more likely where the owner-manager of a firm has a science or technical background (Table 2). In policy terms, it is perhaps of interest to consider the barriers to innovation cited by those micro-enterprises which were making new-to-the-market innovations. Factors which were said to be 'very influential constraints' on innovation were excessive economic risk, $45.4 \%$ of firms; availability of finance, $42.7 \%$; costs of finance, $36.9 \%$ and direct innovation costs being too high, $35.9 \%$ of firms. Other factors like regulatory issues (24.2\%), a lack of information about partners (19.4\%) and uncertain demand (21.4\%) were less commonly cited. The dominance of risk- and finance-related constraints on innovation here is common to most innovation surveys; however, perhaps less common is the finding that $33.9 \%$ of new-to-the-market innovators felt that a major constraint was a lack of information on the potential support available for innovation. This may explain in part the lack of any significant policy effect in our innovation models, although this result is consistent with other recent findings (Conte and Vivarelli 2014).

\section{Conclusions}

Relatively, little is known about the nature of innovation among micro-enterprises with less than 10 employees due to their exclusion from the majority of innovation surveys. Here, we draw on a regional survey explicitly targeted at micro-enterprises to consider the drivers of new-to-the-market innovation and the related process of creative destruction. We find strong support for the interactive nature of new-to-the-market innovation activity among micro-enterprises suggesting the need for a re-definition of the Schumpeterian creative destruction model. The fundamental impetus remains - competition drives innovation - but the process through which innovation and market leadership emerge is interactive rather than atomistic and socially embedded rather than acontextual. Alongside micro-enterprises' internal capabilities, collaboration plays a key role in firms' ability to develop new-to-the-market innovations. Family ownership matters too, increasing the probability that firms will engage in new-to-the-market innovation and drive the creative destruction process.

While our study provides some new insights into micro-enterprise innovation, it has a number of limitations. First, it is based on a cross-sectional survey from a single UK region, Northern Ireland. Both factors limit the generalisability and causal interpretation of the results. Replication with data with broader geographical coverage and a stronger temporal dimension would be valuable. Second, there are some specific limitations to our survey data. In particular, we have no information on the perceived importance of different types of collaboration to each firm or on the specific number of collaborating partners of each type. This limits our analysis of the innovation benefits of collaboration and means we have no insight into the importance of the 'depth' of firms' collaboration (Laursen and Salter 2006). Our data is also limited in terms of the information it provides in terms of the success of the innovations introduced. We are unable to say, for example, whether the new-to-the-market innovations reported proved to be truly disruptive and what implications this had for the innovating firm. Third, although combining some novel leadership and innovation measures, our study remains limited by its econometric and reductionist methodology. Complementary case-study evidence would be a valuable and insightful addition. Finally, while our study does suggest some of the direct influences of factors such as family ownership and co-operation on innovation outputs, we have yet to consider the potential interactions between these influences. Our data shows, for example, that in general, family-owned firms have fewer external innovation partnerships, but it may be that the longer time horizons of family-owned firms allow more complementary partnerships to develop increasing their innovation value. This is for future work.

Acknowledgements We are grateful to the Department of Trade, Enterprise and Investment, Belfast, for allowing us to use the data on which this paper is based. Valuable comments on earlier drafts were received from participants in a Regional Studies Association seminar in Brussels, June 2015, a seminar held in Queen's University Belfast in September 2015 and the Institute for Small Business and Entrepreneurship conference in Glasgow, November 2015. Valuable comments were also received from two referees and the editor of this journal. Errors remain our own.

Open Access This article is distributed under the terms of the Creative Commons Attribution 4.0 International License (http:// creativecommons.org/licenses/by/4.0/), which permits 


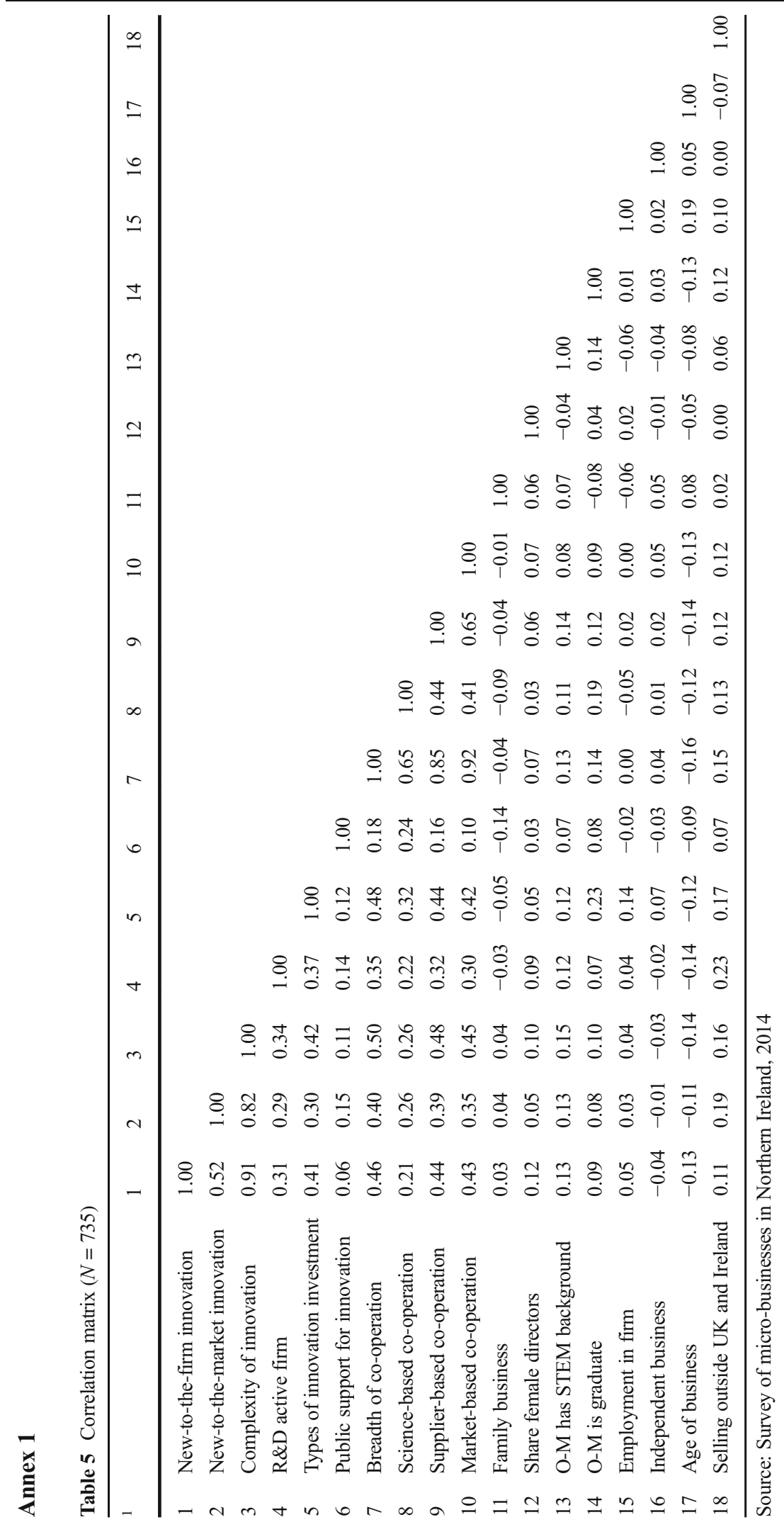


unrestricted use, distribution, and reproduction in any medium, provided you give appropriate credit to the original author(s) and the source, provide a link to the Creative Commons license, and indicate if changes were made.

\section{References}

Adam, E. E., Flores, B. E., \& Macias, A. (2001). Quality improvement practices and the effect on manufacturing firm performance: Evidence from Mexico and the USA. International Journal of Production Research, 39, 43-63.

Allinson, G., Braidford, P., Houston, M., \& Stone, I. (2006). Myths surrounding growing a business: a focus group based study on behalf of the small business service, ed. London: D.o.T.a. Industry.

Arrow, K. (1962). The Economic Implications of Learning by Doing. Review of Economic Studies, 29(2), 155-173.

Astebro, T., \& Michela, J. L. (2005). Predictors of the survival of innovations. Journal of Product Innovation Management, 22, 322-335.

Audretsch, D. B., \& Vivarelli, M. (1996). Firms size and R\&D spillovers: Evidence from Italy. Small Business Economics, 8(3), 249-258.

Balasubramanian, N., \& Lee, J. (2008). Firm age and innovation. Industrial and Corporate Change, 17, 1019-1047.

Ballesteros, J. A., \& Rico, A. M. (2001). Public financing of cooperative R\&D projects in Spain: the concerted projects under the national R\&D plan. Research Policy, 30, 625-641.

Baumann, J. and Kritikos, A. S. (2016). The link between R\&D, innovation and productivity: are micro firms different?, Discussion Paper 1546, DIW Berlin, German Institute for Economic Research.

Beck, M., \& Schenker-Wicki, A. (2014). Cooperating with external partners: The importance of diversity for innovation performance. European Journal of International Management, 8, 548-569.

Belderbos, R., Carree, M., \& Lokshin, B. (2004). Cooperative R\&D and firm performance. Research Policy, 33, 1477-1492.

Bengtsson, L., Lakemond, N., Lazzarotti, V., Manzini, R., Pellegrini, L., \& Tell, F. (2015). Open to a select few? Matching partners and knowledge content for open innovation performance. Creativity and Innovation Management, $24,72-86$.

Benito-Hernandez, S., Platero-Jaime, M., \& Rodriguez-Duarte, A. (2012). Determinants of innovation in Spanish micro-enterprises: the importance of internal factors. Universia Business Review, 104-121.

Bergek, A., Berggren, C., Magnusson, T., \& Hobday, M. (2013). Technological discontinuities and the challenge for incumbent firms: destruction, disruption or creative accumulation? Research Policy, 42, 1210-1224.

Boschma, R. A. (2005). Proximity and innovation: a critical assessment. Regional Studies, 39, 61-74.

Bower, J. L., \& Hout, T. M. (1988). Fast-cycle capability for competitive power. Harvard Business Review, 66, 110-118.

Buiseret, T., Cameron, H. M., \& Georgiou, L. (1995). What differences does it make? Additionality in the public support of R\&D in large firms. International Journal of Technology Management, 10, 587-600.

Cabrales, A. L., Medina, C. C., Lavado, A. C., \& Cabrera, R. V. (2008). Managing functional diversity, risk taking and incentives for teams to achieve radical innovations. $R \& D$ Management, 38, 35-50.

Camagni, R. (1991). Local milieu, uncertainty and innovation networks: towards a new dynamic theory of economic space. In R. Camagni (Ed.), Innovation networks, spatial perspectives. London: New York Belhaven Press.

Cardoso, R. D. R., de Lima, E. P., \& Gouvea da Costa, S. E. (2012). Identifying organizational requirements for the implementation of advanced manufacturing technologies (AMT). Journal of Manufacturing Systems, 31, 367-378.

Carroll, G. (1983). A stochastic model of organizational mortality: review and reanalysis. Social Science Research, 12, 303329.

Chang, Y. Y., \& Hughes, M. (2012). Drivers of innovation ambidexterity in small- to medium-sized firms. European Management Journal, 30, 1-17.

Chesborough, H. W. (2010). Open innovation: a key to achieving socioeconomic evolution: how smaller companies can benefit from open innovation. Tokyo: Japan Economic Foundation.

Choi, S. B., Il Park, B., \& Hong, P. (2012). Does ownership structure matter for firm technological innovation performance? The case of Korean firms. Corporate Governancean International Review, 20, 267-288.

Chrisman, J. J., Chua, J. H., Pearson, A. W., \& Barnett, T. (2012). Family involvement, family influence, and family-centered non-economic goals in small firms. Entrepreneurship Theory and Practice, 36, 267-293.

Christensen, C. M. (1997). The Innovator's Dilemma: When New Technologies Cause Great Firms to Fail. Boston: Harvard Business School Press.

Cohen, W. M., \& Klepper, S. (1996). Firm Size and the Nature of Innovation within Industries: The Case of Process and Product R\&D. The Review of Economics and Statistics, 78(2), 232-243.

Cohen, W. M., \& Levinthal, D. A. (1989). Innovation and learning: the two faces of R\&D. The Economic Journal, 99, 569-596.

Conte, A., \& Vivarelli, M. (2014). Succeeding in Innovation: Key Insights on the Role of R\&D and Technological Acquisition Drawn from Company Data. Empirical Economics, 47(4), 1317-1340.

Craig, J. B., Pohjola, M., Kraus, S., \& Jensen, S. H. (2014). Exploring relationships among proactiveness, risk-taking and innovation output in family and non-family firms. Creativity and Innovation Management, 23, 199-210.

Czarnitzki, D., \& Licht, G. (2006). Additionality of public R\&D grants in a transition economy. Economics of Transition, 14, $101-131$.

Czarnitzki, D., Ebersberger, B., \& Fier, A. (2007). The relationship between R\&D collaboration, subsidies and R\&D performance: empirical evidence from Finland and Germany. Journal of Applied Econometrics, 22, 1347-1366.

de Leeuw, T., Lokshin, B., \& Duysters, G. (2014). Returns to alliance portfolio diversity: the relative effects of partner diversity on firm's innovative performance and productivity. Journal of Business Research, 67, 1839-1849.

Department of Enterprise, T.a.I. (2014). Innovation survey of micro-businesses in Northern Ireland, ed. Belfast: DETI. 
Diaz Perez, C., Alarcon Ozuna, A., \& Ayala Arriaga, A. (2011). Clustering and innovation capabilities in the Mexican software industry. Emj-Engineering Management Journal, 23, 47-56.

Diaz-Garcia, C., Gonzalez-Moreno, A., \& Saez-Martinez, F. J. (2013). Gender diversity within R\&D teams: its impact on radicalness of innovation. Innovation-Management Policy \& Practice, 15, 149-160.

DiMaggio, P J. and Powell, W. W. (1991). 'The New Institutionalism and Organizational Analysis', Chicago: University of Chicago Press.

Filipetti, A. (2010). The role of design in firms' innovation activity: a micro level analysis ed. DIME working paper No 92.

Fosfuri, A., \& Giarratana, M. S. (2009). Masters of war: rivals' product innovation and new advertising in mature product markets. Management Science, 55, 181-191.

Foster, R. (1986). Innovation - the attacker's advantage. London: Macmillan.

Freel, M. S. (2005). Patterns of innovation and skills in small firms. Technovation, 25, 123-134.

Fridenson, P. (2009). The process of innovation: innovative design and business growth. Mouvement Social, 165-166.

Ganotakis, P., \& Love, J. H. (2011). R\&D, product innovation, and exporting: evidence from UK new technology based firms. Oxford Economic Papers-New Series, 63, 279-306.

Garriga, H., von Krogh, G., \& Spaeth, S. (2013). How constraints and knowledge impact open innovation. Strategic Management Journal, 34, 1134-1144.

Glückler, J. (2013). Knowledge, networks and space: connectivity and the problem of non-interactive learning. Regional Studies, 47, 880-894.

Gongora, G., Garcia, D., \& Madrid, A. (2010). The effect of public support on innovative behavior and performance in SMEs. Revista De Ciencias Sociales, 16, 400-417.

Graziadio, T., \& Zawislak, P. A. (1997). The role of informal R\&D activities in the evaluation of the SMEs technological capability - the mechanics industry in Brazil. In In Thirtieth Hawaii International Conference on System Sciences, vol 3-information systems track - organizational systems and technology, ed. J.F. Nunamaker and R.H. Sprague (pp. 518526).

Griffith, R., Redding, S., \& Van Reenan, J. (2003). R\&D and absorptive capacity: theory and empirical evidence. Scandinavian Journal of Economics, 105, 99-118.

Griliches, Z. (1995). R\&D and productivity: econometric results and measurement issues. Oxford: Blackwell.

Grimpe, C., \& Sofka, W. (2009). Search patterns and absorptive capacity: low- and high-technology sectors in European countries. Research Policy, 38, 495-506.

Hargadon, A. B., \& Douglas, Y. (2001). When Innovations meet Institutions: Edison and the Design of the Electric Light. Administrative Science Quarterly, 46, 476-501.

Harris, R. I. D., \& Trainor, M. (1995). Innovation and R\&D in Northern Ireland manufacturing: a Schumpeterian approach. Regional Studies, 29, 593-604.

Hewitt-Dundas, N. (2004). The adoption of AMT and innovation strategy in small firms. International Journal of Innovation and Technology Management, 1, 17-36.

Hewitt-Dundas, N., \& Roper, S. (2009). Output additionality of public support for innovation: evidence for Irish manufacturing plants. European Planning Studies, 18, 107-122.
Hoffman, K., Milady, P., Bessant, J., \& Perren, L. (1998). Small firms R\&D, technology and innovation in the UK: a literature review. Technovation, 18, 39-55.

IntertradeIreland (2012). Leveraging the innovation ecosystem for business advantage: a cross border study, October 2012, Newry: IntertradeIreland.

Keizer, J. A., \& Halman, J. I. M. (2007). Diagnosing risk in radical innovation projects. Research-Technology Management, 50, 30-36.

Kellermanns, F. W., Eddleston, K. A., Sarathy, R., \& Murphy, F. (2012). Innovativeness in family firms: a family influence perspective. Small Business Economics, 38, 85-101.

Kim, Y., \& Vonortas, N. S. (2014). Co-operation in the formative years: Evidence from small enterprises in Europe. European Management Journal, 32, 795-805.

Klepper, S., \& Simons, K. (1997). Technological Extinctions of Industrial Firms: An Inquiry into Their Nature and Causes. Industrial and Corporate Change, 6(2), 379-460.

Kohler, C., Sofka, W., \& Grimpe, C. (2012). Selective search, sectoral patterns, and the impact on product innovation performance. Research Policy, 41, 1344-1356.

Kotlar, J., Fang, H., De Massis, A., \& Frattini, F. (2014). Profitability goals, control goals, and the R\&D investment decisions of family and nonfamily firms. Journal of Product Innovation Management, 31, 1128-1145.

Kraus, S., Pohjola, M., \& Koponen, A. (2012). Innovation in family firms: an empirical analysis linking organizational and managerial innovation to corporate success. Review of Managerial Science, 6, 265-286.

Laursen, K., \& Salter, A. (2006). Open for innovation: the role of openness in explaining innovation performance among UK manufacturing firms. Strategic Management Journal, 27, 131-150.

Laursen, K., \& Salter, A. (2014). 'The Paradox of Openness: Appropriability, External Search and Collaboration', Research Policy. Vol., 43(5), 867-878.

Leenders, M., \& Voermans, C. A. M. (2007). Beating the odds in the innovation arena: the role of market and technology signals classification and noise. Industrial Marketing Management, 36, 420-429.

Leifer, R., McDermott, C. M., o.C.G. C, Peters, L. S., Rice, M. P., \& Veryzer, R. W. (2000). Radical innovation; how mature companies can outsmart upstarts. Boston: Harvard Business School Press.

Leiponen, A. (2005). Skills and innovation. International Journal of Industrial Organization, 23, 303-323.

Leiponen, A., \& Byma, J. (2009). If you cannot block, you better run: small firms, cooperative innovation, and appropriation strategies. Research Policy, 38, 1478-1488.

Leiponen, A., \& Helfat, C. E. (2010). Innovation objectives, knowledge sources, and the benefits of breadth. Strategic Management Journal, 31, 224-236.

Leonard-Barton, D. (1992). Core capabiliteis and core rigidities: a paradox in managing new product development. Strategic Management Journal, 13, 111-125.

Love, J. H., \& Roper, S. (2001). Networking and innovation success: a comparison of UK, German and Irish companies. Research Policy, 30, 643-661.

Love, J. H., \& Roper, S. (2015). SME innovation, exporting and growth: a review of existing evidence. International small business journal, 33, 28-48. 
Love, J. H., Roper, S., \& Vahter, P. (2014). Learning from openness: the dynamics of breadth in external innovation linkages. Strategic Management Journal, 35, 1703-1716.

Lucas, H. C., \& Goh, J. M. (2009). Disruptive technology: how Kodak missed the digital photography revolution. Journal of Strategic Information Systems, 18, 46-55.

Marion, T. J., \& Meyer, M. H. (2011). Applying industrial design and cost engineering to new product development in earlystage firms. Journal of Product Innovation Management, 28, 773-786.

Marsili, O., \& Salter, A. (2006). The dark matter of innovation: design and innovative performance in Dutch manufacturing. Technology Analysis \& Strategic Management, 18(5), 515534.

Martin, L., Warren-Smith, I., Scott, J., \& Roper, S. (2008). Boards of directors and gender diversity in UK companies. Gender in Management, 23, 194-208.

Matzler, K., Veider, V., Hautz, J., \& Stadler, C. (2015). The impact of family ownership, management, and governance on innovation. Journal of Product Innovation Management, 32, 319-333.

Menon, A., Chowdhury, J., \& Lukas, B. A. (2002). Antecedents and outcomes of new product development speed - an interdisciplinary conceptual framework. Industrial Marketing Management, 31, 317-328.

Metcalfe, S. (1997). Technology systems and technology policy in an evolutionary framework. Cambridge University Press.

Moultrie, J. and F. Livesey. (2013). Measuring design investment in firms: conceptual foundations and exploratory UK study. Research policy forthcoming.

NESTA. (2008). Innovation by adoption-measuring and mapping absorptive capacity in UK nations and regions. In October. London.

Oerlemans, L., Meeus, M., \& Boekema, F. (1998). Do networks matter for innovation? The usefulness of the economic network approach in analysing innovation. Tijdschrift voor Economische en Sociale Gcografie, 89, 298-309.

Ostergaard, C. R., Timmermans, B., \& Kristinsson, K. (2011). Does a different view create something new? The effect of employee diversity on innovation. Research Policy, 40, 500-509.

Pangarkar, N. (2003). Determinants of alliance duration in uncertain environments: the case of the biotechnology sector. Long Range Planning, 36, 269-284.

Peters, B., Roberts, M. J. Vuong, V. A. \& Fryges, H (2013). Estimating dynamic R\&D demand: an analysis of costs and long-run benefits, Working Paper Series 19374. Cambridge: National Bureau of Economic Research.

Powell, W. W. (1998). Learning from collaboration: knowledge and networks in the biotechnology and pharmaceutical industries. California Management Review, 40, 228-240.

Rahman, N., \& Korn, H. J. (2014). Alliance longevity: examining relational and operational antecedents. Long Range Planning, 47, 245-261.

Roper, S., \& Hewitt-Dundas, N. (2015). Knowledge stocks, knowledge flows and innovation: Evidence from matched patents and innovation panel data. Research Policy, 44(7), 1327-1340.

Roper, S., Du, J., \& Love, J. H. (2008). Modelling the innovation value chain. Research Policy, 37, 961-977.

Rosenbloom, R. S., \& Christensen, C. M. (1994). Technological Discontinuties, Organizational Capabilities, and Strategic
Commitments. Industrial and Corporate Change, 3(3), 655-685.

Rothaermel, F. T. (2001). Incumbent's advantage through exploiting complementary assets via interfirm co-operation. Strategic Management Journal, 22, 687-699.

Schmidt, T. (2010). Absorptive capacity—one size fits all? A firmlevel analysis of absorptive capacity for different kinds of knowledge. Managerial and Decision Economics, 31, 1-18.

Schumpeter, J. A. (1942). Capitalism, socialism and democracy. New York: Harper \& Brothers.

Sciascia, S., Nordqvist, M., Mazzola, P., \& De Massis, A. (2015). Family ownership and R\&D intensity in small- and mediumsized firms. Journal of Product Innovation Management, 32, 349-360.

Simon, H.A. 1947. Administrative behavior: a study of decisionmaking process in administrative organization Chicago: Macmillan.

Smith, K. (1989). Public support for Civil R\&D in the UK: limitations of recent policy debate. Research Policy, 18, 99109.

Stiglitz, J. E., \& Weiss, A. (1981). Credit rationing in markets with imperfect information. American Economic Review, 71(3), 393-410.

Symeonidis, G. (1996). Innovation, firm size and market structure: Schumpeterian hypotheses and some new themes. Paris: OECD Economics Department Working Papers, 161.

Tiwana, A. (2008). Do bridging ties complement strong ties? An empirical examination of alliance ambidexterity. Strategic Management Journal, 29, 251-272.

Tu, C., Hwang, S.-N., \& Wong, J.-Y. (2014). How does cooperation affect innovation in micro-enterprises? Management Decision, 52, 1390-1409.

Un, C. A., \& Asakawa, K. (2015). Types of R\&D collaborations and process innovation: the benefit of collaborating upstream in the knowledge chain. Journal of Product Innovation Management, 32, 138-153.

Vahter, P., Love, J. H., \& Roper, S. (2014). Openness and innovation performance: are small firms different? Innovation and Industry, 21(7-8), 553-573.

van de Vrande, V., de Jong, J. P. J., Vanhaverbeke, W., \& de Rochemont, M. (2009). Open innovation in SMEs: trends, motives and management challenges. Technovation, 29, 423-437.

Von Stamm, B. (2003). Innovation, Creativity and Design Chichester: John Wiley and Sons

Vossen, R. W. (1998). Relative strengths and weaknesses of small firms in innovation. International small business journal, 16, 88-95.

Xia, H., \& Roper, S. (2008). From capability to connectivity: absorptive capacity and exploratory alliances in biopharmaceutical firms: a US-Europe comparison. Technovation, 28, 776-785.

Zhang, X., Chen, R. Q., \& Ma, Y. B. (2007). An empirical examination of response time, product variety and firm performance. International Journal of Production Research, 45, 3135-3150.

Zhu, Z. H. (2006). The dynamic balance between explorative and exploitative learning under open innovation. In Z. Henry, P. Read, L. Chen, L. Liu, \& C. Zheng (Eds.), Proceedings of the eighth West Lake international conference on SMB (pp. 44 47). Marrickville: Orient Acad Forum. 